Article

\title{
Resurgents Create a Moral Landscape: Indigenous Resurgence and Everyday Practices of Farming in Okinawa
}

\author{
Megumi Chibana \\ Department of International Business and Management, Kanagawa University, Hiratsuka 259-1293, Japan; \\ chibana.megumi@gmail.com
}

Received: 29 November 2019; Accepted: 10 November 2020; Published: 12 November 2020

\begin{abstract}
Located at the territorial border of powerful states in the world, Okinawa has been a politically contested place because of the long and disproportionate hosting of the US military installations in Japan. Historically, the effects of military occupation and control of land appeared in the dispossession of Indigenous land, a transition of the local economy, and furthermore, environmental destruction of agrarian space. This essay examines everyday acts of Okinawans making Indigenous space and making the land a more livable place, despite having long been dominated and militarily occupied. More specifically, this essay explores the correlation between land-based practices of farming and (a)political activism in the community. Drawing upon ethnographic research in Okinawa, I share various stories of people engaged in active Indigenous resurgence, whom I have termed "resurgents." Stories of these resurgents show their commitment to the land-based farming and community-based activism of restoring the Indigenous landscape and foodways. I argue that the everyday act of farming, while perhaps seemingly apolitical and personal, has been and becomes a form of sociopolitical action that not only acts to resist settler-military space but also to sustain firmly and to call forth resurgent Okinawan Indigeneity from the ground.
\end{abstract}

Keywords: Indigenous; resurgence; land; food sovereignty; Indigenous foodways; critical sustainability; farming; Okinawa

All these cultural metaphors of proper behavior are activated in our minds. The way we think about and talk about this place is activated, it's changed. The landscape becomes a moral landscape.

—Enrique Salmón (Salmón 2008)

\section{Introduction}

The main purpose of this essay is to explore agrarian lives of Okinawa as an intersecting case of food sovereignty and Indigenous politics. Like many other Indigenous communities in the world, Okinawa experienced the loss of sovereignty, capitalist accumulation, and exploitation that has greatly transformed the social and economic infrastructures of the island. Also, Okinawa has been a politically contested place because of the long and disproportionate hosting of the US military forces in Japan. The effects of violent occupation and control of land by the military appeared in the dispossession of Indigenous land, a transition of the local economy, and environmental destruction of agrarian space. While I hesitate to simply align Okinawa with Indigenous politics in the Western settler societies, theorization of "settler militarism" (Nebolon 2017) helps us to understand how Japanese and American colonial land acquisitions during wartime and long afterward displaced and disrupted the elements of Indigenous Okinawan settlements. Limited or no access to the land and natural resources triggered some Okinawans to align with global Indigenous movements for their rights to self-determination. 
Meanwhile, persistent land-based practices of Okinawan villagers have also demonstrated a series of Indigenous space transformations.

This essay examines implicit forms of decolonization activism to move a dominant discourse of Okinawan Indigeneity beyond "always resisting" toward "resurging" with the power of everyday practices that build decolonial consciousness. In the processes of reclaiming Indigenous self-determination, the act of resistance presumes the presence of the oppressive force and positions the oppressed in opposition to the force. The rights-based discourse and resistance are necessary, however, not sufficient to lead to sustainable self-determination for Indigenous communities (Corntassel 2008, 2012). Indigenous peoples must shift their brunt of efforts to "the self" (Coulthard 2007; Corntassel 2012). Jeff Corntassel (2012, p. 89) suggests a conceptual shift as he writes, "Decolonizing praxis comes from moving beyond political awareness and/or symbolic gestures to everyday practices of resurgence." As the fundamental point of Indigenous struggles is in "one's relational, place-based existence" (Corntassel 2012, p. 89), individual engagement in resurgence feeds a greater movement for decolonization.

Everyday acts of resurgence constitute a form of political action for Indigenous individuals and communities. It enables them to restore and regenerate relationships to the land, cultures, and communities. Indigenous resurgence is therefore a new strategy, as are efforts by Indigenous individuals and communities that generate homeland consciousness and relationality through everyday dialogues and interactions instead of acting within the statist legal and political structures. I argue that the everyday practices of farming on militarized space constitute the exercise of Indigenous rights and responsibilities to self-determination by making Okinawan presence and practices visible and sustainable. These are Okinawan counterapproaches to settler militarism, which continues to separate, displace, and eliminate Indigenous lifeways. These practices are not the only manifestation of their resistance against the powerful. They resurge from the ground and convey an Indigenous landscape that is full of multiple narratives, memories, and knowledge of the people and the island.

\section{Food Sovereignty and Indigenous Resurgence in Okinawa}

Food sovereignty is a global movement developed with a principle to ensure "the right of nations and peoples to control their own food systems" (Wittman et al. 2010, p. 2). Scholars who support food sovereignty have suggested new forms of food production that features agrarian reform, agroecology, new trade relations, food localization, gender equality, and protection of intellectual property (Allen 2010; Altieri 2009; Andree et al. 2014; Holt-Giménez and Altieri 2013; Patel 2010, 2012; Shiva 1999, 2005, 2013; Wittman 2011; Wittman et al. 2010). While food sovereigntists attempt to counteract neoliberal, market-based food systems, scopes to exercise such radical reforms are often questioned due to states' dominance over policies and trades to govern food production and consumption (Edelman 2014; Edelman et al. 2014; Trauger 2014, 2015; Patel 2012). In many contexts, states remain powerful, exercising their authority over food sovereignty within existing territory and management mechanisms (Edelman 2014; Edelman et al. 2014; Trauger 2014, 2015). Meanwhile, Indigenous peoples remain vulnerable to states' territorial control and global food systems.

Indigenous politics as a field has been dominated by a rights-based approach to sovereignty and self-determination (Corntassel 2008, 2012). Rights imbue the literature on food sovereignty as well. While there are overlapping themes between food activism and Indigenous activism in discussions of sovereignty, citizenship, and territoriality (Grey and Patel 2015; Menser 2014), there are also points of disjuncture. According to Menser (2014), Indigenous sovereignty differs from food sovereignty in three ways by (1) including not only agriculture or food but also cultural practices; (2) being less worker-oriented and more communitarian; and (3) being driven by animist cosmological vision. Therefore, for Indigenous sovereigntists, places are not just ecosystems but also eco-cultural territories and sites of social reproduction (Menser 2014). Moreover, scholars who support an Indigenous resurgence approach challenge centrality of rights and instead advocate for a responsibility-based approach to self-determination (Corntassel 2012). 
In this essay, I highlight the stories of people engaged in active Indigenous resurgence, whom I have termed "resurgents." These resurgents may or may not see connections to each other. However, the affinity that emerges from their stories creates another map of Okinawa, one that moves toward "spatial decolonization" (Goeman 2013) and draws an alternative demilitarized landscape. Mishuana Goeman (2013, p. 3) argues, "(re)mapping is not just about regaining that which was lost and returning to an original and pure point in history, but instead understanding the processes that have defined our current spatialities in order to sustain vibrant Native futures."

This essay connects resurgent farmers across Okinawa, working for decolonial Indigenous futures. Most of these resurgents certainly did not identify themselves as Indigenous rights activists organized to resist colonial structures; however, their everyday acts of resurgence underpinned by their sense of mutual responsibility have slowly transformed my understanding of Okinawan Indigeneity from an unyielding resistance to an envisioning self-determination of futures. Goeman (2013, p. 37) also explains, "Native stories speak to a storied land and storied peoples, connecting generations to particular locales and in a web of relationships." Stories shared by my interlocutors show they are acting beyond resistance to a power dynamic, and (re-)emerging from rooted Indigenous ontologies and epistemologies. I weave these stories together to bridge the generations and scattered localities in Okinawa. It is not to homogenize Okinawan Indigeneity; instead, it is to argue that Okinawans are creating and envisioning more sustainable and inclusive space from various directions while anchoring firmly within the ancestral land.

\section{Resurgent Stories}

\subsection{The Village of Youthful Exuberance}

When I stepped into Wakage no itari mura (The Village of Youthful Exuberance) ${ }^{1}$, I felt as though it were a 21st-century hippie commune. In the late afternoon of Christmas Day, about ten men and women in their 20s gathered in the Village of Youthful Exuberance. This uniquely named "village" is located near Oura Bay in Nago City, northeast Okinawa. When I entered, some villagers were chatting around a fire in the handmade brick oven. Others were picking herbs from their garden. Inside a house, some villagers were learning how to make "effective microorganisms" from horticulturists visiting from Hong Kong. While I was a bit bewildered by the dynamic of this community, my impression completely changed when I began talking with the "mayor" of the village.

The "mayor" of the youthful village, Gushiken Hideaki ${ }^{2}$, was 23 years old at the time of our meeting. Born and raised in Nago City, Gushiken attended a local university. Just like many other Okinawan college students, he was studying English, wishing to have international experiences in the future. "Thinking that the US military base was one of [American] culture," Gushiken worked part-time on the base for four years. While interacting with US soldiers of a similar age who faced battlefield duty, Gushiken soon came to realize the root of the problems that Okinawa is facing. Gushiken said, "It is not that the US soldiers were evil; it is the structure, the root part of the society that is wrong." Gushiken confirmed his ideas while he traveled around Japan. The backpacking trip Gushiken intended to be preparation for traveling abroad instead showed him communities at odds with the state over a lack of support after the Tōhoku Earthquake and Fukushima Nuclear Disaster. Gushiken thought, "There are so many things we need to do here before I go abroad." He took a leave of absence from school and soon began to set up the Village of Youthful Exuberance- "a community to change society." Gushiken found a suitable location on the northeast coast of Okinawa, presented his plan to the community, negotiated, and was granted a space to rent in Futami area to launch his village. Gushiken passionately told me,

1 Unless otherwise indicated, translations are those of the author.

2 Both in the text and references, Japanese names are listed following traditional usage (i.e., family name followed by the given name). I chose to use a pseudonym for my research participants who preferred to remain anonymous. 
After all, [we] always get wound up in tolerating the military, especially the US military, because of their approach to "conserve" the environment. The root part is that ... we, in this capitalism, consume too much, and the culture of deprivation already exists. If we want to change it, we must change the lifestyle itself. I am not saying to live frugally, but to live the life that matches with the times ... So, we rent the farmland, and we grow food. We want to complete [the cycle] from production to distribution with our own brand and hammer out a new industry for the east coast. This [side] is an area that has been swayed by the issues of Henoko and Takae. ${ }^{3}$ When the community is asked for a counterproposal, the economic situation of the community has led [people to] think that they need [the military bases]. So, we will make new counterproposals early and say, "we can do it [without the bases]." I want to undivide the community again. The worst scenario is to lose the good culture of Okinawa because of the politics and money. I do not want that. That is how I decided to do this here on the east coast.

While facing various issues in his eclectic village, Gushiken and villagers are eager to create an alternative form of community. In Okinawa, like other militarized places, the presence of the military is normalized within the hegemony of colonialism, capitalism, and patriarchy through constant reconstructions of militarized spaces (Enloe 2007; Ferguson and Turnbull 1998; Lutz 2009). "I was frustrated about the Henoko issue because the thought that 'nothing will change no matter what we do' is getting rooted in people's minds," Gushiken said. In fact, many of the Okinawan youth, who know Okinawa only as fenced, share the same frustration Gushiken feels. Meanwhile, their youthful exuberance has demonstrated their power to uproot the frustration and replace it with the passion for unseen possibilities. At least Gushiken's village was already functioning as a new hub for the Okinawan youths to gather, learn about, think about, and practice how they want to create their future life on this island.

\subsection{An Invited Young Farmer}

Nine months after launching, the Village of Youthful Exuberance has become a space where passionate young resurgents gather to exchange emerging concerns and new ideas in the neighborhood. One day at the youthful village, I met Ano Shōdai, a 26-year-old part-time farmer from Kayō community of Nago City. Several encounters, including people's kindness and his sense of reciprocity, encouraged Ano to move into Kayō in 2016. At the time of my first meeting with Ano in January 2017, the population of Kayō Community was only 66, mostly elderly residents. Ano said, "If a man is in his 60s and still can move, he is considered of the 'young generation' here." In 2009, the Kayō Elementary School, along with three neighboring schools, merged. More than 20 houses in this small community are vacant, with only a family altar left inside. Many spaces are considered abandoned agricultural land. The young adults of the community had left and moved to cities for professional and educational opportunities. Though some come home to help with physical labor needed when traditional ceremonies are held, Kayō is one of the rural communities severely affected by the issues of aging, depopulation, and a stagnant community.

Ano started visiting Kayō to volunteer in community events when he was a college student. As he interacted with the elders, Ano was well received by the community, and eventually these relationships inspired him to start farming in Kayō. Ano told me about the current challenge he faces:

[The hardest thing is] the relationship with the community and farmers when we make decisions that affect their ways of living. If I do something that ignores their ideas, even their very identity, it triggers an emotional reaction. Sometimes, things I do would divide the

3 Henoko and Takae are the places in northern Okinawa where the construction of new US military bases began in 2015 as a replacement for the US Air Station Futenma in central Okinawa. The construction has been controversial because the Japanese government pressed forward with the plan, ignoring persistent local opposition. 
community into people who agree and disagree. Such human relationship is real, indeed. It is not like something that a young person who wants to do agriculture suddenly comes in and he can do it.

After earning a college degree, Ano now works at an agricultural cooperative entity, Okinawa Harusā Club, whose goal is achieving "sustainable and ecological agriculture" (Yanbaru Harusā Purojekuto Jimukyoku 2017). Ano's main job is to promote local agriculture and support new young farmers. While promoting organic, multi-crop farming and new farmer initiatives, the Club also supports rural revitalization (Yanbaru Harusā Purojekuto Jimukyoku 2017).

In addition to this job, Ano began rice farming on a field leased from a Kayō man. "I want to make rice that can tell traditions, cultures, and stories like... 'In the old days, Kayō was famous for rice farming ..."' Ano said with smile. "With rice straw, the community used to make a rope for the tug-of-war event, but [the tradition] has not occurred for 50 years." In that time, there was nobody who farmed rice. About seven years ago, a few people in the community suggested rebuilding rice fields to restore the landscape of the old times. When Ano learned about restoring rice fields, he occasionally visited the community to volunteer. As Ano passionately supported the idea, a community leader invited Ano to work on his field. Inspired by this young farmer's initiative, a few other neighboring farmers also began to work on restoring their rice fields.

The effort to rebuild rice fields in Kayo is culturally rooted in healthily sustaining the land, water, and people. Since rebuilding rice fields takes tremendous work, the community initiatives proceed slowly. First, waterways need restoring because the surrounding sugar cane fields-although currently abandoned-have filled the paddies. During the 50 years when rice was not farmed, sugar cane became Kayō's main cash crop to survive the capitalist agricultural economy. ${ }^{4}$ Growing sugar cane in Kayō's unsuitably wet soil shows how capitalism negatively affected the Indigenous farmscape and economic (un)development of the community. Meanwhile, creating space for rice fields encourages the transformation of lands and waters and ignites the resurgence of the sustainable Indigenous community. "Why rice? Isn't it because it was staple food? When farmers began to focus on growing cash crops, rice farming in Okinawa declined. That is why it ceased, and people shifted [to growing] sugar cane," Ano recounted. Although rice farming in Kayō is less competitive with larger rice production sites in mainland Japan, growing staple foods in their own fields is important for community members greatly affected by changes in the agricultural economy.

As Ano took me to his rice field and showed me around the community, I noticed that his knowledge of Kayō extends beyond just rice farming. Pointing at "the god of water," he told me a whole story of how the Kayō community emerged, how sacred spaces are maintained, why they have been important for the community, and how the community has enshrined them. At the top of the community's utaki (a sacred grove on a hill), we looked down at the village, and Ano described the landscape of Kayō:

There are mountains behind, then flat fields and community, then ocean ... This was a traditional orientation of communities in Okinawa. This, being surrounded by mountains, is called kusatimui, which means 'back support hill.' [With kusatimui], this community is protected, according to feng shui.

As this young farmer learns the stories and traditional knowledge of Kayō, he fosters his feeling toward the community. Seeing the aging community through his own eyes, Ano wishes to preserve the unwritten Indigenous cosmology of the community.

4 Due to the mountainous landscape, rice cultivation in low wetlands was encouraged and spread in northern Okinawa; however, the paddy fields have gradually decreased since 1910s (Ryūkyū Seifu [1972] 1989, p. 476). 


\subsection{Base Farmers}

"In Sobe, people who engage in agriculture mostly [farm] in Torii Station. The space inside the base was the basis of our livelihood," Higa Takashi, a leader of the Sobe community, said. Higa continued, "In Sobe's case, our community's geographical locale is itself a reallocated area, which was created after the war." Entering the neighborhood, one quickly understands what Higa meant. Unlike other communities, the Sobe neighborhood is crammed with houses side by side and narrow roads with many parked cars. Far beyond the fence of the US Army Garrison Torii Station, which separates the community, one can see military facilities in a vast field and the two national flags of the Stars and Stripes and the Rising Sun swaying in the breeze.

On 15 May, 1951, United States Civil Administration of the Ryukyus ordered the eviction of the Sobe community for base construction (Aza Sobe-shi Henshū Iinkai 1999). Despite villagers' many petitions and sit-in protests against the eviction, the US military began surveying the land and building new facilities (Aza Sobe-shi Henshū Iinkai 1999). In a state of postwar poverty in an agrarian community like Sobe, the loss of the land was debilitating. Facing the crisis of losing the living space, the community negotiated and reluctantly agreed to the terms proposed by the military, which included the military permitting villagers to farm any area that they did not use (Aza Sobe-shi Henshū Iinkai 1999, p. 102). Having enough space for farming was a crucial factor in the negotiation to maintain the villagers' livelihood.

Currently, farmers of the Sobe community are mostly elderly, retired, part-time farmers. Only a few are full-time farmers. With the aging of the original landowners, some are second-generation farmers who inherited the land from their families. With a special entry permit with a facial photo, farmers go through a "farmer's gate" of Torii Station every day to water and take care of their farm plots.

In the summer of 2014, second-generation farmers Reiko and her husband Haruo took me inside Torii Station and showed me their farm plots. Although the landscape inside the fence was mostly covered with vast sugar-cane fields and vegetable gardens, it was the remains of houses and big Okinawan-style tombs that made me keenly aware of the previous presence of the community. "Do you want to go to Uganju?" Reiko asked me, referring to a place of worship, as we went around the farming sites in her small car. As a former elementary school teacher, Reiko remembered the time she took pupils inside the base on a school excursion and showed them the community's sacred places. "Kabigingaa. Here is kaa (a water well)." She pointed out and continued, "Places where kaa were... spring water used to come out of the ground. Here, there is no more water. It's all dried out. There are always plants, shinboku like this." I asked, "What is shinboku?" She said, "It's yorishiro. It's an object to which spirits are drawn. There are usually [shinboku] at uganju (a place of worship). Villages were located facing towards these tall trees [and uganju]."

In Sobe, elders call the community settlement before the displacement "furu-Subi" (old Sobe) and the current ward after relocation "mii-Subi" (new Sobe). In furu-Subi, which is now partially enclosed within the military barbed-wire fences, there are 11 sacred sites for prayer. According to local folklore, these sites are considered sacred because of the abundance of water and suitable feng shui placement. While land-based belief and practices have become simplified, these sacred sites in Sobe have been protected by the hands of volunteer farmers like Haruo and Reiko. When the Army tried to build another facility on sacred sites, the farmers negotiated with the Army. The farmers requested to set up signs in English to indicate the sacred sites and pay respect to these sites.

For the native villagers, protection and governance of the sacred sites have laid a spiritual groundwork that founded and supported the community in a different realm from the basic infrastructure. The ontology of the communities does not consist of only the physical and geographical orientation and governance; rather, it is a living space that embraces polysemic worldviews and even transgresses the boundaries of the non-human world. This way of remembering and reclaiming space is counterhegemonic in the ways that they emphasize Indigenous relationality to the land. What I thought might be "Indigenous," "traditional," or "historical" no longer stays static in the past or exists only in material form. Indigenous cosmology encompasses the land, the people, and the 
spirits. Through the telling and retelling of stories, Indigenous connection to the land in this space is maintained, fortified, and cherished.

\subsection{A Community Revitalization Activist}

Kinjō Takiro is a founding member of the non-profit organization the Phoenix Group. Currently consisting of 45 members, the Phoenix Group works to connect the landscape, food, and people of Yomitan (Ōtori-kai n.d.). They also work on event organization, local production and local consumption of food, environmental conservation, and human resource development. While Kinjō calls himself an activist of community revitalization, he is also an owner of an Okinawa soba ${ }^{5}$ restaurant in Yomitan. "Empowered by the resurgence of Yomitan from 90\% military space," Kinjō wishes to repay kindness and bring the vitality of the younger generation to the village. As he proclaims, Kinjo has initiated event planning to boost the development of the community with the Phoenix Group members. In a 2015 column series in the local newspaper Okinawa Taimusu, Kinjō (2015) writes,

"Community revitalization" began with "self-revitalization" to confirm my own existence and identity in the society. Although feelings of ambivalence and anxiety struck me many times, I kept going. Who am I? How do I live? I repeated this conversation with myself as I cooked ... By always reminding myself of "appreciation," I began to feel closer to agriculture that stands next to everyday "food." With locally produced foods such as tōmāmì miso, vast wheat fields, freshly caught fish at the Toya Harbor, this agrarian village with a heart full of dedicated local love reminded me of my identity as I live as an Okinawan.

Kinjō self-identifies as "half" Okinawan. Born to a Japanese mother and an Okinawan father, Kinjō spent about 17 years in mainland Japan. Reflecting on his childhood and the time when he moved back to Okinawa as an adult, Kinjō thinks his life was not easy. In the 1970s, Kinjō's father played a major role in the social movement to protest the oil-storage construction and landfilling on Kin Bay, the east coast of Okinawa Island. Witnessing how his father devoted much of his life in the forefront of protest activism, Kinjō prioritizes "feeding the family" with his business rather than being involved in social movements. Meanwhile, his experience of finding his identity as an Okinawan is represented in his Okinawa soba, which is served in a non-traditional style. Kinjō said, "[Being denied my soba] was like being denied myself ... because my mother was naichi (Japanese). It made my ambivalent state of mind more complex."

Self-reflection and interacting with a community through soba making have eventually brought him to find happiness living in the community. One day, a wheat farmer in Yomitan suggested Kinjō make his Okinawa soba out of $100 \%$ locally grown wheat. In prewar Okinawa, similar to rice farming, wheat cultivation was a common practice; however, it ceased and was replaced by sugar cane and other cash crops. After the war, Okinawan people made soba with flour brought and distributed by the US military. The basic ingredient of Okinawa's signature dish now relies on imported flour from the United States and Canada. While the fact of dependency on imported flour reflects the history and reality of Okinawa as entangled with food security and sovereignty, Kinjō writes, "It is sad if Okinawa soba, the identity of Okinawan people, is a product made abroad." Kinjo joined the Okinawa Wheat Production Co-op, which was formed in 2015. One of the objectives of the Wheat Production Co-op is to convert abandoned farmland to organic wheat fields while encouraging the food security and safety of Okinawa. Kinjō began engaging in wheat farming, making homemade soba noodles, and now serves Okinawa soba made of locally produced wheat.

In Eating the Landscape, Enrique Salmón (2012) describes food as a part of our life that entails a comprehensive understanding and decolonization of ourselves. Salmón (2012, p. 13) writes,

5 Okinawa soba is one of the cultural foods from Okinawa. It is a type of thick wheat noodle in a soup flavored with seaweed, bonito flakes, and pork. Standard toppings include fish cake, pork belly, and pork ribs. While soba in Japan means buckwheat noodles, wheat is used to make Okinawa soba entirely. 
"The responsibility of growing food for one's community is connected to one's identity as a member of the community. This identity, this sense of 'being-ness,' is tied to the history of the people on a landscape." In Kinjō's soba making, his personality, strong passion, and persistent character are projected in its processes and practices. For Kinjō, making Okinawan soba has become a journey of his own self-realization while reflecting on the history of the people and food system. Alfred and Corntassel (2005, p. 611) state, "The larger process of regeneration, as with the outwardly focused process of decolonization, also begins with the self." Kinjö's self-consciousness and personal re-orientation in the community bring him forward to renew his commitment to his place-based life and further strengthen his participation in community resurgence.

\subsection{The Ōyama Taanmu Fan Club}

"People today don't have enough appreciation for food," Nakama Ken said in frustration. He continued, "People just make money from real estate. Then the cost of land gets so high, for profits of millions of yen [for some people]. Here, farmers work so hard to make hundreds and thousands of yen. Then we get taro. That is how ... and what it means to get food. It is the compensation for the hard work." Five years ago, Nakama and his wife Shiori, with taro farmers in Oyama, Ginowan City, organized the "Taro Fan Club," which focuses on activities that promote the appeal of taanmu (taro) and taabukkwa (taro patches) in Ōyama. Nakama and his family live in Ginowan City, an area adjacent to the US Marine Corps Air Station Futenma, which is known as the most dangerous air station in the world due to its location in a crowded urban area (Japanese Perspective 2015; Tiezzi 2015). When Nakama and Shiori moved back from mainland Japan to Nakama's hometown with his family, they were looking for a "natural environment" where their kids could play outside. Eventually, Nakama found his childhood "playground" of taro patches in Ōyama, but he also saw the rapid development. Witnessing the urban growth of his hometown encouraged Nakama and Shiori to start activities to convey the beauty of taro while preserving the historical taro patches.

Taro patches in Oyama spread about 40 hectares towards the west between Route 58 and the coastline. Surrounded by new buildings and roads, the presence of taro patches in an urban area seems surreal. Ōyama is historically known for an abundance of water that comes from a limestone cave in Futenma. While many entrances to the limestone cave were found upland of Futenma, the actual conditions underground are not known because the Marine Corp occupies a large part of the upland area and entry is restricted. Around the taro patches, there are 13 water sources that were (and have been) used for domestic and agricultural purposes by farmers and residents.

As I, led by Nakama and Shiori, strolled alongside the taro patches, we came across a taro farmer named Miyagi Minoru. Miyagi is a second-generation organic taro farmer. Miyagi recalled, "I did not like farming because I did not want to get dirty. I had always thought this area should get filled soon." While Miyagi disliked farming when he was young, his life hit a turning point when he was in his mid-30s, and now he thinks farming is his "real vocation." Miyagi finds his calling in the idea of coexistence. He said, "[Coexistence] is the ecosystem we had when I was using this place as a playground ... coexistence with living things. I do not want to kill living organisms to make food we eat." Miyagi learned how the land had weakened from repeated cultivation for profit.

Miyagi, as well as Nakama and Shiori, believes that the weakening of the land is also attributed to increasing pressure for development that has diminished the number of taro patches. In Öyama, there are about 40 taro farmers who belong to the taro farmers' association, and many of them lease the land to grow taro. As the city carries out the land readjustment project, new buildings and roads gradually have enclosed a vast taro field. In 1968, Ginowan City adopted an urban planning ordinance on the farmland that used to be famous for taro farming (Shima 2009). The trend toward greater urbanization filled many acres of farmland and wetland in Ginowan and converted those areas to residential and commercial use. While facing enormous pressure for development, the taro farmers' association took actions by lobbying the City to preserve the Ōyama taro patches. In response, in 2008 the City formulated the Basic Plan for Ōyama Taro Patch Promotion, aiming to promote urban 
agriculture (Shima 2009). Based on the Plan, about 15 out of 49 hectares will be secured and preserved as farmland (Shima 2009). However, for the farmers, the Plan looks like merely a formality of the historic preservation of the farmscape that does not promise actual coexistence of the people with the ecosystem.

The generation shift among landowners has also shaped the flow of the city. The number of landowners at the beginning of the city planning period increased from approximately 300 to more than 600 due to the generation change and inheritance. Miyagi said, "People who inherited the land do not farm. The number of landowners is increasing. No one opposes filling the patches up front, but not even 10 percent of [landowners] come to the meeting to discuss this." Miyagi is irritated with the "silent majority" of landowners. "In many cases, the landowners lease the land to taro farmers. So [landowners] do not understand the feelings of farmers. They are so distanced. They do not even think to preserve the taro patches," Shiori added.

In addition to the pressure for urbanization, in December 2016, PFOS (perfluorooctanesulfonic acid), a fluorinated organic compound and pollutant coming from Futenma, was detected in high levels in the Ōyama groundwater (Ryūkyū Shimpō 2016). Since there was another case of finding PFOS and other toxic chemicals near Kadena Air Base at the beginning of 2016, the Okinawa Prefectural Government now inspects the Futenma Air Base for use of the chemical substance (Mitchell 2016; Ryūkyū Shimpō 2016). "I think the chemicals triggered some people to quit farming," Miyagi said helplessly. Although the situation remains tough for an organic taro farmer, Miyagi hopes to recover the power of the land by increasing microorganisms in place of using pesticides or chemical fertilizers.

The situation also bothers Nakama, who works at the construction department of the city government. He says, "Civil engineering should be for people's livelihood ... not to destroy trees that survived for decades in a few hours." For Nakama, land readjustment projects have made the land into a disposable commodity. The city and land developers constantly seek an untouched area to exploit and develop the land in a human-centered way. Nakama stressed, "A planned cityscape may look good, but man-made things are temporary after all." While understanding that infrastructure development creates convenience in the city, Nakama strongly wishes for land use that draws on the original landscape.

The Ōyama Taanmu Fan Club, although it started small, has slowly worked to revive the landscape and the ecosystem that can still be found in taro patches. In 2015, Ginowan City set 6 February as the day for taanmu (taro), promising to highlight taro as a traditional vegetable and signature product of Ginowan. The city encourages citizens' taro production and consumption. Through the promotion of taro, the Club hopes citizens will realize the beauty of taro patches, the importance of a recycling-oriented ecosystem, and the interconnected land and resource system in their living environment. In Ōyama, the resurgence of an Indigenous landscape through taanmu has just begun.

\subsection{A Landscape Designer}

"I am yaadui ${ }^{6}$ of Tamagusuku," Inafuku started off by saying when he greeted me. Inafuku is 63 years old and owner of a popular café and lodging facilities in Tamagusuku. After leaving his profession as a civil engineering consultant, Inafuku opened his first café at a beachfront in southern Okinawa in 1995. Located in an "obscure area," his style of land use and café did not receive positive reactions from the local community in the beginning. Inafuku calls himself a "landscape designer." He says, "I am not a land developer. I measure charms of the rough from various perspectives and polish the land. People see the refined land. People who resonate with my style join in; then [my project] becomes one for the community." His café and other facilities make full use of the natural

6 Yaadui refers to a community formed by the upper class who lost their jobs and moved to rural areas in the early 18th century after the annexation of the Ryukyu Kingdom (Okinawa Daihyakkajiten Kankō Henshūkyoku 1983). 
landscape and create eco-friendly space where visitors enjoy the stunning scenery of the ocean and gardens. While some may have opposed Inafuku's unconventional approach to land use, his passion and dream eventually gained understanding from residents. His landscape designing has brought more collaborators and expanded, and it is now called "Sachibaru no Niwa (The Happy Garden)." "Although half of those who were moved [by my project] to take action are Japanese," he said with a complex look on his face while he told me, in the mixed use of Japanese and Okinawan, about how he had worked for ecological space-making in Tamagusuku.

Tamagusuku in southern Okinawa, which was merged with other towns to become Nanjo City in 2006, faces a different kind of landscape transformation from that of central and northern Okinawa. While land use and communities in central and northern Okinawa have largely been affected by the US military occupation, the absence and distance from the army forces in southern Okinawa has left a suburban landscape that attracts increasing numbers of tourists and migrants from mainland Japan. In fact, half of Inafuku's employees and collaborators are Japanese migrants who were lured by the beauty of rural Okinawa. People, in accordance with his style of land use, moved in, bringing more like-minded people in, and a new community began to form. Due to the distance, the US military occupation is not an immediate concern for communities in southern Okinawa. Instead, slight tensions and friction between Okinawans and Japanese migrants seem to have emerged from complacency and insensitivity toward the history of the place and the people and might have displaced the centrality of Indigenous agency while (re)producing settler colonial structures. Inafuku is keenly aware of these tensions and friction between Uchinaanchu (Okinawan) and Yamatonchu (Japanese) that arise from working together to create "coexisting" community space. Inafuku said,

If you do not care, you do not need to care. There are problems anywhere you go. But if you care ... how do I say ... This is Okinawa's land. Why can't we, Okinawans, encourage [ourselves] to take the lead to enhance the land [and welcome those who resonate]? What is this invisible gap [that lies between Okinawans and Japanese]? If I raise this as a question, it is a big question, you know. ${ }^{7}$

Inafuku avoided articulating or drawing a clear line between Okinawans and Japanese because "it will be called 'reverse discrimination." In Okinawa, "reverse discrimination" has been used to refer to situations when Okinawans differentiate themselves from Japanese migrants and claim native relationship to the land. It has been called so because in Okinawa, Japanese migrants are a numerical minority and both groups are the same citizens and residents of Okinawa Prefecture. Being a numerical minority helps the Japanese migrants play the role of disadvantaged victims of discrimination by Okinawans.

Ignorance of the history of the place and the people and inattention to settler positionality allows migrants to disregard the Indigenous relationship to the land in the process that Wolfe calls the "logic of elimination" (Lloyd and Wolfe 2016; Wolfe 2006; Veracini 2011). It also increases the risk of further undermining Okinawan will for self-determination. The faces of a couple of Japanese migrants came to my mind as I wrote this. In fact, these Japanese migrants were the ones who introduced me to and connected me with some of my research participants. These migrants escaped from the busyness of urban life and moved to the culturally and ecologically beautiful and attractive island. The migrants I conversed with were very humble about the everyday politics they are learning about and were respectful of Okinawan self-determination. They, too, as migrants, were questioning their own positionalities and responsibilities and exploring ways to coexist in Okinawa peacefully. After all, frictions do not necessarily stem out of the differences among people but out of different understanding of Indigenous space and place.

7 Translation here is not done literally. The author refers to a previous conversation in the interview and has paraphrased it in the translation. Also, the interviewee uses a mixture of Japanese and Okinawan. 
While Inafuku is sensitive to talking about "the absolute root" of friction, which lies in the power imbalance between Japan and Okinawa, he strongly wishes initiatives and leadership to be taken by Okinawans for land planning. Homogenized, manualized, and state-centered urban planning and real-estate dealings based on productivity are no longer appealing for him. Inafuku believes that a unique economic system of Okinawa is not competition, which he described as an "adverse effect" of capitalism rooted in naichi (Japan), but rather coexistence. As his narrative implies, the growing discussions of environmental conservation and food safety in Okinawa have not yet reached the point of critically questioning the agency over green spaces. Rather, they have created a structure for who should and can participate in ecological space-making in Okinawa. Thus, the power and privilege that migrants intentionally or unintentionally bring into Indigenous space has become obscured. Instead, some Okinawans are left feeling uncomfortable and insecure about articulating what they have believed in and how they wish to proceed with the land.

I asked Inafuku if he likes his current lifestyle. He replied to me in a half serious and half humorous tone,

When I was working in Naha, I was lying to myself. I do not do that now. So, I prefer being here. Why? This place taught me the natural way of living. The trees, the ocean, and the fish. I clearly learned how people live according to the lunar rhythm. Fish and trees taught me ... I knew it when I was little. Why do suku [mottled spinefoot, a fish] come to the beach only on the first of June, July, and August of the lunar calendar? How do they know the first day of the lunar calendar? They must have studied in a university! Their professor must have told them to go to the shore on 1 June of the lunar calendar. And, fishermen knew it from the old days. There is no question there ... and so do crabs! Crabs go to the beach on the full moon night, 15 May to September [of the lunar calendar] from 6 p.m. to 9 p.m. when the tide is high. They go to the beach to lay eggs. How do they know? ... When I was working in Naha wearing a tie, I acquired skills to live like in Tokyo ... You go to mind seminars and learn Japanese language intonation. You must copy the Tokyo way of sneezing to become Japanese...

After I came back to [Tamagusku, although] I knew it when I was little, [I learned] the depth of nature. A human being is not in a special status among animals, plants, and all living creatures. In our mind, there is a sensor like fish and crabs. When there was no electricity like 50 years ago, my parents' generation, the sensor was working and shining. They knew when a typhoon would come by feeling the wind, without checking the weather forecast. They knew when to plant seeds by looking at the moon. There was no question. It was nothing special. It was part of their life cycle ... When I started working in the city, my sensor got very rusted. However, after I came back, I feel like the rust fell off a bit.

Inafuku's passion pervades his landscape designs. He said with a pleased look, "If you are an owner of café, it's a café. For me, the café was just my way of seeding." Inafuku also started wheat farming and became a member of the Okinawa Wheat Production Co-op. The group strictly prescribes their commitment to organic, non-chemical, and non-pesticide wheat farming. As soon as he ensures the stable supply of his organic wheat, he intends to make homemade pizzas offered in his café out of his wheat. Indigenous narratives of connecting food, culture, language, landscape, traditional knowledge, biodiversity, spirituality, and others remind us how colonialism has impacted every aspect of Indigenous life (Salmón 2012). Inafuku said confidently, "If you know what you are doing, you do not need to say. You do not need to belong to environmental organizations. You do not need to advocate. You do not need to argue. You do not fight ... nature tells you. And, you have pride in your way of life ... I am not an environmental conservationist, but I love nature." 


\section{Conclusions: The Landscape Becomes a Moral Landscape}

In Okinawa and elsewhere, the language of environmentalism overwhelms Indigenous resurgence and fails to acknowledge everyday practices that thread seemingly compartmentalized aspects of Indigenous well-being together. Likewise, growing consciousness about food security among consumers focuses on having justice in the food supply but conceals how food producers understand the space and the land-based practices. My research participants' forms of growing food align with the agroecological movement to create a new paradigm to approach a more sustainable and inclusive food system. However, their approach to food is not limited to gaining rights to control the food system or farming environment. Here, food functions as metaphor for the resurgence of Indigenous livelihood. My research participants actively engage in growing food. As food producers in various ways, the set of everyday practices they engage in leads to thinking and talking about the place we live in.

My ethnographic research targeted narratives of small-scale farmers in rural Okinawa. My observation from talking with them is that all of them cherish Indigenous epistemology and ontology while practicing farming. Farming for them is not only about producing food. They farm because of their connection to the land, their reciprocity and responsibility to the ancestors and the community, and their desire to articulate their moral landscape to future generations. Stories of the landscape and farmscape underscore the Native relationship to the land and serve as the backbone of these farmers' committed practices.

Through farming and food production, these practitioners plant seeds of indigenizing the landscape. "Indigenizing means 'repurposing,'" Kamuela (Kamu) (Enos 2017), Hawaiian community activist and Social Enterprise Director at MA'O Organic Farms in Hawai'i, explains. Kamu practices and commits to the community-based social enterprise through organic farming. He stresses that indigenizing means to fulfill one's ancestral responsibility (Enos 2017). I, too, argue that what I have heard, observed, and interpreted from these practitioners in Okinawa are acts of repurposing the existing structures to be vehicles for ancestral principles. They think carefully about what their ancestral practices offer and how they are offered, and they explore various ways to indigenize the space and to reconnect with the community.

This essay has sought to provide personal narratives that highlight Indigenous agency. Cultural and personal forms of narratives by each resurgent provide imminent and underlying reasoning that assists in interpreting certain phenomena. Rooted in different locations in Okinawa, the scope of each practice does not always reach out or work in collaboration with each other. Each of them have their own objectives, methods, and goals. What these resurgents have in common is that they choose to grow food. As these resurgents find themselves working with the people, the environment, and the system, they came to realize disconnections in their lifestyle and communities. Growing food has emerged as an alternative way to acknowledge land-based knowledge and the experiences of people on the ground and to create a new paradigm to tackle the issues of controlling and accessing shared resources and fundamental aspects of human life in their surroundings. In other words, farming and food production have become their methods to practice self-determination through an agroecological lifestyle. Such practices of self-determination decenter the state or "politics." Rather, they focus on the land and its self-generating capacity for the future. Moreover, in their narratives and practices, they rediscover and reconnect Indigenous food, culture, knowledge, spirituality, and other aspects of Indigenous life that were submerged in militarized and capitalized landscapes. By tilling the soil and growing food, Indigenous resurgents add a layer of a moral landscape in Okinawa.

Funding: This research received no external funding.

Acknowledgments: The author thanks the anonymous referees for their valuable suggestions and comments.

Conflicts of Interest: The author declares no conflict of interest. 


\section{References}

Alfred, Taiaiake, and Jeff Corntassel. 2005. Being Indigenous: Resurgence against contemporary colonialism. Government and Opposition 40: 597-614. [CrossRef]

Allen, Patricia. 2010. Realizing justice in local food systems. Cambridge Journal of Regions, Economy and Society 3: 295-308. [CrossRef]

Altieri, Miguel A. 2009. Agroecology, small farms, and food sovereignty. Monthly Review 61: 102-13. [CrossRef]

Andree, Peter, Jeffrey Ayres, Michael Bosia, and Marie-Josee Massicotte. 2014. Introduction: Crisis and contention in the new politics of food. In Globalization and Food Sovereignty: Global and Local Change in the New Politics of Food. Edited by Peter Andree, Jeffrey Ayres, Michael Bosia and Marie-Josee Massicotte. Toronto: University of Toronto Press, pp. 3-19.

Aza Sobe-shi Henshū Iinkai. 1999. Aza Sobe-Shi: Minzoku-Hen. Yomitan: Aza Sobe Kōminkan.

Corntassel, Jeff. 2008. Toward sustainable self-determination: Rethinking the contemporary Indigenous-rights discourse. Alternatives 33: 105-32. [CrossRef]

Corntassel, Jeff. 2012. Re-envisioning resurgence: Indigenous pathways to decolonization and sustainable self-determination. Decolonization: Indigeneity, Education $\mathcal{E}$ Society 1: 86-101.

Coulthard, Glen. 2007. Subjects of empire: Indigenous peoples and the "politics of recognition" in Canada. Contemporary Political Theory 6: 437-60. [CrossRef]

Edelman, Marc. 2014. Food sovereignty: Forgotten genealogies and future regulatory challenges. The Journal of Peasant Studies 41: 959-78. [CrossRef]

Edelman, Marc, Tony Weis, Amita Baviskar, Saturnino M. Borras Jr., Eric Holt-Giménez, Deniz Kandiyoti, and Wendy Wolford. 2014. Introduction: Critical perspectives on food sovereignty. The Journal of Peasant Studies 41: 911-31. [CrossRef]

Enloe, Cynthia. 2007. Globalization and Militarism: Feminists Make the Link. Lanham: Rowman \& Littlefield Publishers.

Enos, Kamuela. 2017. Decolonizing pedagogies. Paper presented at Panel Discussion at the Decolonizing Cities Symposium by the Kamakakūokalani Center for Hawaiian Studies and the Department of Urban \& Regional Planning, Honolulu, HI, USA, May 5.

Ferguson, Kathy E., and Phyllis Turnbull. 1998. Oh, Say, Can You See: The Semiotics of the Military in Hawai'i, 1st ed. Minneapolis: University of Minnesota Press.

Goeman, Mishuana. 2013. Mark My Words: Native Women Mapping Our Nations. Minneapolis: University of Minnesota Press.

Grey, Sam, and Raj Patel. 2015. Food sovereignty as decolonization: Some contributions from Indigenous movements to food system and development politics. Agriculture and Human Values 32: 431-44. [CrossRef]

Holt-Giménez, Eric, and Miguel A. Altieri. 2013. Agroecology, food sovereignty, and the new green revolution. Agroecology and Sustainable Food Systems 37: 90-102.

Japanese Perspective. 2015. Relocation of Futenma Base. April 9. Available online: http://japaneseperspective. com/relocation-of-futenma-base/ (accessed on 10 September 2017).

Kinjō, Takirō. 2015. Karajishi. Okinawa Taimusu, July 13-December 28.

Lloyd, David, and Patrick Wolfe. 2016. Settler colonial logics and the neoliberal regime. Settler Colonial Studies 6: 109-18. [CrossRef]

Lutz, Catherine. 2009. Introduction: Bass, empire, and global responses. In The Bases of Empire: The Global Struggle against U.S. Military Posts. Edited by Catherine Lutz and Cynthia Enloe. New York: NYU Press, pp. 1-44.

Menser, Michael. 2014. The territory of self-determination: Social reproduction, agro-ecology, and the role of state. In Globalization and Food Sovereignty: Global and Local Change in the New Politics of Food. Edited by Peter Andree, Jeffrey Ayres, Michael Bosia and Marie-Josee Massicotte. Toronto: University of Toronto Press, pp. 51-83.

Mitchell, Jon. 2016. Contamination: Kadena Air Base's dirty secret. The Japan Times, April 9.

Nebolon, Juliet. 2017. Life given straight from the heart': Settler militarism, biopolitics, and public health in Hawai'i during World War II. American Quarterly 69: 23-45. [CrossRef]

Okinawa Daihyakkajiten Kankō Henshūkyoku. 1983. Okinawa Daihyakka Jiten. Naha: Okinawa Taimusu Sha.

Ōtori-kai. n.d. NPO Hōjin Chiiki Shinkō Ōendan: Ōtori-Kai. Yomitan, Okinawa. Acquired. June 4. 
Patel, Raj. 2010. What does food sovereignty look like? In Food Sovereignty: Reconnecting Food, Nature and Community. Edited by Hannah Kay Wittman, Annette Aurelie Desmarais and Nettie Wiebe. Oakland: Food First Books, pp. 186-95.

Patel, Rajeev C. 2012. Food sovereignty: Power, gender, and the right to good. PLoS Medicine 9: e10001223. [CrossRef] [PubMed]

Ryūkyū Seifu. 1989. Okinawa Kenshi: Keizai. Tokyo: Kokusho Kankōkai, vol. 3. First published 1972.

Ryūkyū Shimpō. 2016. Futenma Chikasui Kara Kagaku Busshitsu Beigunkichi Yurai ka, Kōnōdo 'PFOS'. December 27. Available online: http://ryukyushimpo.jp/news/entry-418404.html (accessed on 9 June 2017).

Salmón, Enrique. 2008. Restoring indigenous history and culture to nature. In Original Instructions: Indigenous Teachings for Sustainable Future. Edited by Melissa K. Nelson. New York: Simon \& Schuster, pp. 88-115.

Salmón, Enrique. 2012. Eating the Landscape: American Indian Stories of Food, Identity, and Resilience. Tucson: University of Arizona Press.

Shima, Yōko. 2009. Nōchi to takuchi kyōzon kaihatsu ye, Ginowan-shi Ōyama, shinkōkeikaku matomaru. Ryūkyū Shimpō, March 3.

Shiva, Vandana. 1999. Biopiracy: The Plunder of Nature and Knowledge. Boston: South End Press.

Shiva, Vandana. 2005. Earth Democracy: Justice, Sustainability, and Peace. Cambridge: South End Press.

Shiva, Vandana. 2013. Making Peace with the Earth. Halifax: Pluto Press.

Trauger, Amy. 2014. Toward a political geography of food sovereignty: Transforming territory, exchange and power in the liberal sovereign state. Journal of Peasant Studies 41: 1131-52. [CrossRef]

Trauger, Amy. 2015. Putting food sovereignty in place. In Food Sovereignty in International Context: Discourse, Politics and Practice of Place. New York: Routledge, pp. 1-12.

Tiezzi, Shannon. 2015. Beyond Futenma: Okinawa and the US Base Conundrum. The Diplomat, November 4.

Veracini, Lorenzo. 2011. Introducing. Settler Colonial Studies 1: 1-12. [CrossRef]

Wittman, Hannah. 2011. Food sovereignty: A new rights framework for food and nature? Environment and Society: Advances in Research 2: 87-105.

Wittman, Hannah Kay, Annette Aurelie Desmarais, and Nettie Wiebe. 2010. The origins \& potential of food sovereignty. In Food Sovereignty: Reconnecting Food, Nature and Community. Edited by Hannah Kay Wittman, Annette Aurelie Desmarais and Nettie Wiebe. Oakland: Food First Books, pp. 1-14.

Wolfe, Patrick. 2006. Settler colonialism and the elimination of the native. Journal of Genocide Research 8: 387-409. [CrossRef]

Yanbaru Harusā Purojekuto Jimukyoku. 2017. Yanbaru Harusā Purojekuto. Available online: http://haruser.jp/ (accessed on 22 May 2017).

Publisher's Note: MDPI stays neutral with regard to jurisdictional claims in published maps and institutional affiliations.

(C) 2020 by the author. Licensee MDPI, Basel, Switzerland. This article is an open access article distributed under the terms and conditions of the Creative Commons Attribution (CC BY) license (http://creativecommons.org/licenses/by/4.0/). 